\title{
Greenhouse gas emissions from solid and liquid organic fertilizers applied to lettuce
}

\begin{abstract}
Improper application of nitrogen $(\mathrm{N})$ fertilizer and environmental factors can cause the loss of nitrous oxide $\left(\mathrm{N}_{2} \mathrm{O}\right)$ to the environment. Different types of fertilizers with different $\mathrm{C} / \mathrm{N}$ ratios may have different effects on the environment. The focus of this study was to evaluate the effects of environmental factors and four organic fertilizers (feather meal, blood meal, fish emulsion, and cyano-fertilizer) applied at different rates $\left(0,28,56\right.$, and $\left.112 \mathrm{~kg} \mathrm{~N} \mathrm{ha}^{-1}\right)$ on $\mathrm{N}_{2} \mathrm{O}$ emissions and to track $\mathrm{CO}_{2}$ emissions from a lettuce field (Lactuca sativa $\mathrm{L}$.). The study was conducted in 2013 and 2014 and compared preplant-applied solid fertilizers (feather meal and blood meal) and multiple applications of liquid fertilizers (fish emulsion and cyanofertilizer). Three days a week, $\mathrm{N}_{2} \mathrm{O}$ and $\mathrm{CO}_{2}$ emissions were measured twice per day in 2013 and once per day in 2014 using a closed-static chamber, and gas samples were analyzed by gas chromatography. Preplant-applied solid fertilizers significantly increased cumulative $\mathrm{N}_{2} \mathrm{O}$ emissions as compared with control, but multiple applications of liquid fertilizers did not. Emission factors for $\mathrm{N}_{2} \mathrm{O}$ ranged from 0 to $0.1 \%$ for multiple applications of liquid fertilizers and 0.6 to $11 \%$ for preplant-applied solid fertilizers, which could be overestimated due to chamber placement over fertilizer bands. In 2014, solid fertilizers with higher $\mathrm{C} / \mathrm{N}$ ratios (3.3-3.5) resulted in higher $\mathrm{CO}_{2}$ emissions than liquid fertilizers ( $\mathrm{C} / \mathrm{N}$ ratio, 0.9-1.5). Therefore, organic farmers should consider the use of multiple applications of liquid fertilizers as a means to reduce soil greenhouse gas emissions while maintaining high yields.
\end{abstract}

Keyword: Greenhouse gas emissions; Solid organic fertilizers; Liquid organic fertilizers; Lettuce 